\title{
A qualitative Pastoral Care Model on teenage care in the Methodist Church of Southern Africa
}

\author{
Xolisa Jibiliza \\ Centre for Theology and Religion \\ University of Fort Hare \\ 1 King Williams Town Road \\ Alice, 5700, South Africa \\ Email: xjibiliza@yahoo.com/jibilizax@gmail.com \\ Doi: https://doi.org/10.46222/pharosjot.1034
}

\begin{abstract}
This paper sought to explore the perceptions of and the experiences of the Methodist Church of Southern Africa (MCSA) on teenage care in territories of the Port Elizabeth North Circuit. It is during adolescence that religious beliefs and values are anticipated to begin to assume the same meanings that they have in later life. The study, from which this paper is derived, was informed by a qualitative approach using a case study design. The study also used interviews complemented by focus group discussions as data collection methods. The study comprised 22 participants who remained anonymous, that were selected through the use of a purposive sampling technique. This paper revealed the following thematic findings: Convictions on the lives of teenagers, teenager's habits that affect behavior, observation of teenagers' aggressions. Furthermore, this paper employed a pastoral care approach as a theoretical or conceptual framework and made the following recommendations: There is need for the MCSA to have committees that will formulate structures for sustaining projects and give an account of finance utilization as many teenagers drop out from school for financial reasons. The MCSA, Department of Social Development, NGOs and the Department of Health should work together to strategize on structuring the welfare of children in communities general. The MCSA should take into account all the special conditions that are associated with child abuse. The Methodist should develop a teenage care policy and integrate it into its existing polices.
\end{abstract}

Keywords: Teenage care, teenage pregnancy, substance abuse, Methodist Church.

\section{Introduction}

The approach to the topic takes the definition of the teenage care as a starting point to reflect on the role of the Methodist Church of Southern Africa (MCSA) on teenage care in the Port Elizabeth North Circuit in the Eastern Cape Province in South Africa. The researchers used twenty two respondents and delved into a brief discussion of the findings. This study begins by highlighting the concept of teenage/adolescent care.

Teenage care is defined in a constricted sense because some scholars like Charlotte Weston, Elizabeth Aparicio, Akadiri, Bakare and Ajenifuja restrict teenage stage on their definitions.. Longman's English Dictionary defines care as 'the process of looking after someone or something that needs attention'; as 'responsibility for'; 'paying attention that you do not damage or hurt someone or something', and 'a feeling of worry or concern or unhappiness'. In the context of this study, the term 'care-worker' is associated with people who give practical support and care to 
those in different stages of HIV and AIDS (Srivastava, Nyamathi, Sinha, Carpenter, Satyanarayana, Ramakrishnan, \& Ekstrand, 2017).

This study sought to define teenage care, as the teenagers need some special care due to the vulnerability that they have through their developmental period. The adolescence/teenage stage becomes awkward within children's social setups, as they are suddenly self-aware (Gee, Maskell, Newcombe, Kimble, \& Williamson, 2020). At this stage of life, adolescents/teenagers may find themselves confused and anxious about whether they fit in with their social peers. They often reject their parents' values (Gee, Maskell, Newcombe, Kimble, \& Williamson, 2020). In their search for independence, and during their sexual maturity and moral dilemmas, teenagers also often feel excluded and misunderstood (Gee et., 2020). Doka (2011: 1) explains how 'throughout teenage stage, the teenager struggles with three core issues: independence, intimacy and identity'. The Christian God is understood as a caring God, and caring is an aspect of the vision we seek for our world. It is also our duty to care we are instructed to love our neighbor (Mark 12:28ff; Matthew 22:39), and show mercy and compassion. Love, mercy, and compassion are also values to be upheld and applied in making moral decisions in relation to others on. Compassion, love and mercy are virtues to be cultivated and practiced by the Christian. All of these aspects of care/caring are central in moral life and consequently for those in training for ministry. Nicolaides states that "Christian ethics applies to Christian faith and positive servant leadership motivations based on deep spirituality which is required to link in a manner which allows for the desired principles, standards, and procedures for actions and a set of divinely inspired virtues to be in place with relevance to all economic activity. In the modern world in which we live there is seemingly very little agreement regarding desired standards of good or ethical behaviour" (Nicolaides, 2020).

The formulation of caring teenagers hinted at a significant shift from viewing children as objects of mission to seeing them as people in mission themselves (Kim \& Anderson, 2011:156). There was a passion about the issue of children in mission, but also concern about the care of teenagers, their potential for exploitation, and the right recognition of childhood. The theological-missiological rationale for children in mission seemed to have been that Jesus placed a child among his disciples and also the key roles in mission played by several children in the Bible. "Religious faith, beliefs, and activities are important aspects of the lives of American adolescents. Although researchers have found a general age trend for religiousness to decline from childhood through adolescence" (Bridges \& Moore, 2002).

That was the behavior of the $17^{\text {th }}$ and $18^{\text {th }}$ centuries and it is similar to our time as childrens' needs and care were neglected to an extent in society. We must learn the importance of raising children in the home and the church with Christian values of love and discipline. The church should be the place/institution where teenagers are molded and guided towards full potential. The teachings of the church should make children aware of the difference between right and wrong, instilling in them the means of grace and the love of God and other persons. In some families, parents do not have time to sit with their children to give them proper guidance in their teenage years due to work. Therefore, the Methodist Church has the vital role to nurture those children and give them Christian values of love and discipline. Malinga (2006: 112) stresses that what you do every day, what you say and how you act will do a lot to shape the future of your child and of the society. MacAdams (2013: xii) concurs with Malinga when addressing the notion of generativity as an adult's concern for commitment to promoting the welfare and development of the future generations. Moreover, he said, what is critical is the concern for or commitment to making the world far better for your children or other people's children, for the next generation and for generations to follow. The notion of generativity according to MacAdams is concerned about the parenting, teaching, nurturing and caring for young people. 
Chisale (2014: 55) states that children are spiritual beings and furthermore Chisale cited in Hadley (2007:25) as argues that assumptions by the church about the spiritual nature of the child are the result of a lack of a contextual model of pastoral care for children, particularly those in a crisis situation. The church needs to develop practical theological models to shape the church's pastoral care for children. Chisale (2014: 55) stresses that the responsibility of the church should begin with theological academics, such as practical theologians, who need to work caringly with the church to create and develop models that will be used when the flock of God are in need.

The teenage stage is the stage that is discernible by a crisis of identify, as teenagers seek acceptance in the adult world and among their peers (Qambata, 2011: 8). A crisis is the combination of danger and opportunity (Cheng \& Conca-Cheng, 2020).

The teenager has choices to make and these choices concern who the teenager wants to be and the values that he/she want to embrace, which may come at a cost for most. While the teenagers may not want to disappoint their parents, they would also want to fit in with their friends and the youth or popular culture that they so eagerly embrace. Teenagers find it difficult to establish equilibrium between these two realities. They have to learn that the choices that they make, affect them and also those around them. Teenagers are members of a larger community and at some stage, their actions, either on a small or large scale, have consequences within the society in which they live. The teenage caring phase is a process that takes place in between childhood and parenting that consist of biological and cultural factors based on the sexuality of the child. Qambata (2011: 7) argues that during the transitional period between childhood and adulthood, children often spend less time with their parents and more time with their peers. Furthermore, she says they are more interested in the opposite sex and display insecurity, conflict and struggle over appropriate avenues of expression. Being a teenager is not as easy as people think. Teenagers participate in many activities that may lead them to behave badly. Therefore, they need special care and nurturing to have a valuable life. Coulson (2010) suggests that living progressions that happen throughout teenage years make the teenager ready for regenerative work. Qambata 2011: 7 further stresses that this period is marked by teenagers eventually seeking acceptance from the grown-up reality and, furthermore, from their circle of close friends.

Although constructions of childhood change from time to time, there are also clear differences between societies on how teenagers are viewed and treated in diverse cultures. Even within societies, there are considerable differences that affect how teenagers experience the stages (Kopchak-Sheehan, Burke-Draucker, Christ, Murray Mayo, Heim \& Parish, 2014). The process of teenage caring involves perhaps experimenting with drugs, alcohol, sex and them placing their heath and other people's lives in danger. Throughout the process of bad behaviours, some might make mistakes that include initial sexual experimentation that may result in early pregnancy. Baumgartner and Buchanan (2010: 92) state that caring for and helping teenagers is an important aspect of nurturing their spiritual lives, as it helps them feel valuable and enhances their sense of belonging. There are basic needs that children require: to be cared for, to be clothed, to have quality education in school and in the church, to have good nurturing and proper accommodation and finally to have immunization from ill- health. Yohani, (2010) explores methods of improving the caring for children and concludes that it is important to nurture a trusting relationship with a child. Teenagers in many countries across the globe are exposed to the high risk of unplanned pregnancy and substance abuse.

Teenage Pregnancy: the researchers construed that some family and religious problems may lead to teenage pregnancy. Bullies and unapproachable parents are enablers of teenage pregnancy. O'Neill (2011: 93) argues that it is not surprising that teenage pregnancy has long been highlighted as extremely high in many South African communities. This is the result of the 
lack of sex education of children by the parents. Parents do not want to talk about sex to their children to make them aware of the consequences sexual practices. They wait for the child to get pregnant first and then start telling child about consequences. Therefore, the lack of parental supervision contributes to teenage pregnancy. Dual orphans are more than twice as likely to experience an unwanted pregnancy before they are mature enough, when compared to paternal orphans and children with both parents alive

\section{Substance Abuse}

O'Neill (2011: 94) states that the abuse of alcohol and drugs is recognized as a major problem among South African teenagers, and this is also the case in many developed nations. Teenagers abuse substances for various reasons, such as parental conflict, peer pressure and poverty. Alcohol is a very powerful drug, which reduces symptoms of stress and anxiety. Because growing up is associated with feelings of frustration, social anxiety, depression and anger, teenagers often deal with these pressures by turning to alcohol and drugs. Teenagers with undiagnosed and unmanaged anxiety problems are at a higher risk for abusing alcohol (Ndlangisa, 2012: 1). Some teenagers' abuse substances because they do not want to face the realities in their life, but others abuse substances because of intense peer pressure.

There is no single reason as to why individuals engage in excessive use of psychoactive substances. Various contextual, social and individual factors are cited as contributory factors to the excessive use of psychoactive substances (Hobkirk et al, 2016: 103). At an individual level, it is argued that the overwhelming rigors of daily life often become a contributing factor in substance abuse (Lebese et al., 2014: 335). Thus, the use of substances becomes a mechanism to cope with life stress. In a study on the experiences of "nyaope" users participants stated that the drug had helped them in escaping the loss of a child, loss of both parents, anger about an absent father, family conflicts and an unhappy marriage (Mokwena \& Huma, 2014: 357). It is worth noting that among teenagers the reasons for experimenting with drugs mainly emanates out of curiosity (Lebese et al., 2014: 334).

The idea of curiosity being one of the key factors that introduces teenagers to the use of drugs is also supported by other authors (Donald, 2007). This phenomenon of experimentation is not only common among teenagers but also adults (Hobkirk et al., 2014: 104). Social factors also play an influential role in the abuse of addictive drugs. These factors include the perceptions that are most prevalent in the community about the use of drugs and peer pressure. Hobkirk et al, conducted a qualitative study of methamphetamine (tik) initiation in Cape Town and found that the participants in the study, all methamphetamine users, were of the view that within their communities, tik had a somewhat trendy popularity (Hobkirk et al, 2014: 102). Lebese et al., stretch this concept and in their study suggest that drug use is seen as "moja", the coolest feeling ever that every teenage boy wants to be associated with (2014: 334). The perceptions of the community on the use of substances in highly intertwined with peer pressure and a social drive to fit in within the user's social circles. There is a very strong social bond among users of drugs. This is confirmed by Mokwena and Huma's study into the experiences of nyaope users (2014: 357). Social context is deemed to be a very critical factor in the use of substances. Drugs are fast becoming ubiquitous in South African Society, more so in the black and coloured communities. It must be noted that this is the strata of South African society that is the most ravaged by a lack of socio-economic opportunities, poor educational facilities as well as recreational avenues (Hobkirk, 2014: 105).

\section{The Methodist Church (MCSA) on Teenage Caring}

At present, there is no research by the Methodist Church on teenage caring, although there is a department called Children's Ministry to care for children. In 2013, the Methodist Church of 
Southern Africa established a Child Care Desk to place special focus on caring for children from age six to nineteen. Even though these two programs exist to nurture children, teenagers in the Port Elizabeth North Circuit are still involved in unacceptable behaviors, such as substance abuse and teenage pregnancy.

This is the reason why the article focuses on the study of substance abuse and teenage pregnancy. This process may help them reclaim their dignity. What the researcher has attempted to do is to contribute to helping the Methodist Church become an even more caring community that empowers teenagers and supports them in their development as human beings of value to themselves and also to others in their communities.

\section{Theoretical Framework}

This research paper focused on the important role played by the broader church in caring for teenagers, healing and transformation, Children's Ministry and the role of the MCSA in the lives of teenagers. The researcher investigated the issue of caring for teenagers by the Methodist Church of Southern Africa in the Port Elizabeth North Circuit utilizing the pastoral care approach. The pastoral care approach is that aspect of the ministry of the church concerned with the wellbeing of the individual and the community (Smit, 2015).

This research paper was guided by Gerkin's shepherding method of pastoral care. This theory or method was deemed apt for this research as it relies on a triangular shape in its function. Gerkin's (1997: 23) biblical traditional method of shepherding involves the trialogical structure of priests, prophets, wise men and women and is based on an understanding of the way in which these individuals collectively took authority in shepherding God's people in the Old Testament.

Gerkin's approach focuses both on individual and family needs. He points out that pastoral care involves both the care of the Christian community and the care of persons: individually, in families, and in large group relationship (1997: 113). This is in contrast to the psychotherapeutic pastoral care model common in America and Western pastoral care. Gerkin's approach to pastoral care has been advanced by many African scholars. For example, Tapiwa Mucherera argued that therapy or counseling, as taught in the West, will not always suffice in indigenous contexts since these theories tend to promote and focus on individuality, autonomy and independence (2009: ix). Gerkin (1997: 23) outlined pastoral care to the ancient leadership of Israel who were the priests, a hereditary class that had particular responsibility for worship and ceremonial life, the prophet who spoke on behalf of God in relation to moral issues, sometimes rebuking the community and its government leaders, and the wise men and women who offered counseling of all sorts concerning issues of good life and personal conduct. All these offices have been merged, in the Methodist Church of Southern Africa into the office of the minister.

It is evident from the matare held, that the offices of the prophet and wise men and wise women are not functional in the Methodist Church of Southern Africa as it was in the ancient Israel. The ministers are not extremely concerned with the care and discipline of God's people, both the congregation and as individual members in the sphere of teenage care. The minister has to display God's care in the prophetic acts of leadership and confrontation with implications of the will of God for mutual care of people, that is, care for all human affairs (Gerkin, 1997: 24). This kind of care should prompt us to confront issues of justice and moral integrity in the life of the teenager. Gerkin urges that to care pastorally for people is to consistently inquire about and help the people consider the morality of their actions. It is high time that teenagers are compelled to consider morality of their conduct in the prevailing teenage stage struggling period. Pastors are ideally situated to do so as no one else seems to have the heart to act. This approach can be so useful in addressing the needs in the teenagers' lives through pastoral homilies. Moreover, the 
Methodist ministers have to engage with the issues of teenage care and offer guidance concerning about the caring of vulnerable teenagers, contrary to the seemingly current indifferent stance of some. The Methodist Church minister should also assume another model of the caring leader shepherd, which is most clearly captured in the imagery of Psalm 23 . The pastor can take a cue by reflecting on the actions and words of Jesus as he related to people at all levels of social life.

\section{Research Methodology}

The research employed the qualitative research method which entails a generic approach to research where the research takes as its exit point, the insider's perspective on action (Babbie, 2010: 229). Researchers have long debated the comparative value of qualitative and quantitative inquiry (Yilmaz, 2013a). Qualitative research uses a naturalistic approach that seeks to understand phenomenon in context-specific settings (Yilmaz, 2013b).

In the qualitative approach, one collects numerous forms of data and examines them from various angles to construct a rich and important picture of a complex situation. The qualitative component of the research which involves re-telling and analyzing data from members of childrens ministry, ministers, children ministry's practitioners and stewards is helpful because it is, in fact, these people who gave the researcher an opportunity to examine strong features of Practical Theology in the context of teenager's life experience. Those strong features are recorded by Osmer (2011: 2) as:

$>$ Descriptive-empirical: What is going on? Gathering information to better understand particular episodes, situations, or contexts.

$>$ Interpretive: Why is this going on? Entering into a dialogue with the social sciences to interpret and explain why certain actions and patterns are taking place.

$>$ Normative: What ought to be going on? Raising normative questions from the perspectives of theology, ethics and other fields.

$>$ Pragmatic: How might we respond? Forming an action plan and undertaking specific responses that seek to shape the episode, situation, or context in desirable directions.

\section{Data collection}

In qualitative research, data collection occurs at the site where the researcher approaches the participants in their own location. Interviews were conducted in the form of structured questionnaires and unstructured questionnaires prepared for collecting data at the respective sites. Interviews were carried out with a group of members, namely: the three ministers of the PE North Circuit, Circuit Stewards, Children Ministry Practitioners (CMP's) and teenagers that are representing the Circuit as part of the programme. The interviews were strictly confidential for the people who participated in this study.

\section{Data analysis}

The total number for PE North members who participated in the study was twenty two (22) respectively. Males were ten (9) while females were twelve (13). The participants were so proactive and willing in providing information with regards to their experience children. Respondents were Children's Ministry Practitioners 4, Minister 3, Circuit Stewards 3 and teenagers 12.

Children's Ministry Practitioners are believed to spend more time with these children and look after these children on their needs in various aspects like financially, socially and emotionally. It 
is not so easy to get information spontaneously from Xhosa children. This approach was useful in the sense that it involved parents in real life issues regarding their teenage care.

The design of the questionnaire used was in a general standard questionnaire that suits all of the respondents. This was meant to accommodate ministers, stewards, children's ministry practitioners and teenagers. The demographic profile of the participants included: age, gender, levels of education, socio-economic status and marital status. This was the case with all the respondents that were interviewed. Ethical considerations were attended to in the course of this study. The researcher analyzed the data that he found from the site by formulating the following themes. The findings that came from the respondents guided the researcher to select the themes properly. Data analysis has multiple facets and approaches, encompassing diverse techniques under a variety of names, and is used in different business, science, and social science domains.

\section{Study findings}

\section{Convictions on the lives of teenagers}

It is a strong statement to be speaking of the care for teenagers by the Methodist Church of Southern Africa in genera,I and in Port Elizabeth North Circuit in particular. As a matter of fact, children are quite conspicuous in their efforts to obtain care from MCSA, even when the church is purportedly aimed at the entire human race or the whole church. The MCSA is increasing the field of mission by factoring children into it, or by making children part of the mission focus; the main purpose of the MCSA is to advance the following argument: children are forcing a new theological hermeneutic onto the MCSA, which is beginning to make some people wonder whether we are not confronted with a new epistemological break.

The research questions asked during the study were not whether adults care for or teach (or venerate) children (White, 2011:5). To some extent, the questions are whether adults begin to understand that from the perspective of children, there is an entirely different way of knowing the Kingdom or reign of God. The research questions were consequently not about the sharpening and the improvement of Sunday school, the children's ministry, or the children's service once a quarter or perhaps more frequently.

Participants stated that even though they felt neglected at home and in society at large by their mistakes or by what they experienced in life, the MCSA became their place of comfort. Some participants stated that they experienced rape by their step fathers at some point, that they reported to their mothers. Primavera, Judith Jackson, Shelley, (2013) argue that many experts believe that sexual abuse is the most underreported form of child maltreatment because of the secrecy or conspiracy of silence that so often characterizes these cases. Some respondents stressed that their mothers were not working the only person who is the bread winner was the person that abused them. Their mothers decided not to open any legal cases because they did not want to lose the support of the bread-winner, instead they asked their children not to speak about what the person did to them. The parents and other guardians have an important role to play in the protection of children from sexual violence. Each child has the right to protection from all forms of physical or mental violence, injury or abuse, maltreatment or exploitation, including sexual abuse, while in the care of parent(s), legal guardian(s) or any other person who has the care of the child. However, parents in a sense misunderstand their responsibilities as they sometimes force their children to be secretive as a means of protecting the perpetrators. There are issues that are in relation to a child's right to express his or her viewpoint, to have freedom of thought and access to information and so on. It is important to stress the parents' role in reporting sexual violence against girls and possibly also boys, in the community. 
The role of government is to assure that parents have the facilities to care for the children. Political instability and economic underdevelopment sometimes force parents to marry off their daughters early. It is the responsibility of the government to provide welfare structures for its citizens, including children. It is thus vital to focus on the role of parents and guardians in cases of domestic gender-based sexual violence.

Participants agreed that as they grew up they experienced many things such as physical abuse from inside families and outside families (Community) by individuals. Primavera, Judith Jackson, Shelley (2013), stated that physical abuse is characterized by the non-accidental infliction of physical injury as a result of punching, pushing, striking, kicking, biting, burning, shaking, or otherwise harming a child. The parent or caretaker may not have intended to badly hurt the child; rather, the injury may have resulted from over-discipline or physical punishment.

Participants stated that they felt physical neglected by their parents at home. There are many deferent kinds of neglect. Child neglect is regarded as an abuse. Child neglect is characterized by failure to provide for the child's basic needs. Neglect can be physical, educational, or emotional. Physical neglect includes refusal of, or delay in, seeking health care, food, clothing, or shelter; abandonment; expulsion from the home or refusal to allow a runaway to return home; and inadequate supervision.

Primavera, Judith Jackson, Shelley (2013), also stated that educational neglect includes the allowance of chronic truancy, failure to enroll a child of mandatory school age in school, and failure to attend to special educational needs. Emotional neglect includes such actions as marked inattention to the child's needs for affection; refusal of or failure to provide needed psychological care; spouse abuse in the child's presence; and permission of drug or alcohol use by the child. The assessment of child neglect requires consideration of cultural values and standards of care, as well as recognition that the failure to provide the necessities of life may be related to poverty.

Participants agreed that there is an emotional abuse that they have experienced from parents, family members, friends and other community members. Emotional abuse is also a maltreatment perpetrated towards teenagers because it damages the mind of a child. Primavera, Judith Jackson, Shelley (2013) assert that emotional abuse (psychological or verbal abuse or mental injury) includes acts or omissions by the parents or other caregivers that have caused behavioral, cognitive, emotional, or mental injury. In some cases of emotional abuse, the acts of parents or other caregivers alone, without any harm evident in the child's behavior or condition, are sufficient to warrant intervention and investigation by the Child Protective Services (CPS).

\section{Teenager's habits that affect behavior}

There were many deferent opinions from respondents about teenage habits that affect their behaviour, therefore, the researcher considered the observations from the ministers, stewards, children's ministry practitioners and teenagers who are the members of children's ministry. All three ministers agreed that youth have a time of intense growth and development that needs energy to increase; therefore they should pay attention to eating properly. The choice of dishes and meals are based on the habits of families. Adolescents are not given much information about the importance of proper nutrition by experts, while on the other hand they tend to choose restrictive diets (Mihajlovic, Tasovac, Dikanović, Vignjević, 2000).

Eating habits of teenagers significantly influence the choice of foods, frequency and timing of daily consumption. Eating habits are acquired in childhood. Eating habits of people significantly influence the choice of foods, frequency and timing of daily consumption. Eating habits are acquired in childhood. From the kind of food teenagers consume the most frequently, it is evident 
that the teenagers eat meal that is bought not prepared at home and they also eat it when they arrive home.

Two of ministers agreed that teenagers that display the said eating habits are likely using drugs such as dagga, or other medications. The concurrent usage of multiple substances during the teenage stage is a serious public health problem that makes teenagers eat more than required. Given the importance of understanding interdependence in substance use during the teenage stage, the purpose of this section is to look at the co-evolution of cigarette smoking, alcohol, and marijuana use within the ever-changing landscape of adolescent friendship networks, which are a primary socialization context for teenage substance use. Wang, Hipp, Butts and Lakon (2018) stated that high correlation of alcohol and marijuana use may be due to a shared genetic risk for drug use.

Wang et al (2018) stress that adolescent substance use yields insight into potential patterns regarding which drugs are used sequentially. As these risk behaviors co-occur and accumulate over time for certain individuals and social groups, there is potential to concentrate risk and negative consequence among these concurrent users making them a high risk population that may be in need of prioritized and targeted intervention. In addition, to the extent that use of one substance affects the usage of another among adolescents, accounting for this interdependence in substance use is important as it can minimize the possibility of obtaining spurious relationships and possibly biased model estimates. Wang et al (2018) further stated that the complementary usage of tobacco and marijuana in adolescence may contribute to the eventual dependence on nicotine. Furthermore the complementary usage of these two substances might be the greatest public health consequence from marijuana use in adolescence.

Four Childrens' Ministry Practitioner (CMPs) suggested that teenagers are more like his or her peers, two of the CMPs argued that there is a peer influence through modeling, shared opportunities, social proximity and the merging with attitudes and behaviors that may take place in teenage friendship networks. Apart from experiencing all this emotional upheaval, the adolescent now starts developing the ability to think critically (Doka, 2011; Piaget, 1972:12). Teenagers have to learn that the choices that they may make affect them and also those around them. Teenagers are part of a larger community and on some level, their actions, whether on a small or large scale, have consequences within that community. The ability to choose actions wisely contributes a fundamental role in the purpose and participation of peoples' search for answers to the vital questions in life. The MCSA is very strong on the doctrine of "Free will" that allows a person to choose what is right and what is wrong. The choices that people make might:

Shape their life in a meaningful way. A civilized culture needs individuals who have developed ways of expressing and communicating their emotions, who are sensitive to the transrational, who have a language for their deepest longings and anxieties and for the encounters with the beautiful and the uncanny. (Heimbrock 2010:129)

Sometime teenagers choose to follow depraved things that affect their whole life and are not reversed throughout. Such teenagers are often disregarded adults and are unsure of the aspects required for a good life and how to conduct themselves general. Selection of what to do and what not to do is very important and wisdom is acquired gradually. Jibiliza (2016: 72) argued that another challenge facing poor young girls that live in these areas is that they often have great peer pressure placed on them because they see others' material possessions and have relationships with older rich men who would happily pay for these relationships. The researcher observed that there are of course a range of many other positive behaviors via which the supporting of youth for at least a period within the church can result in positive behavioral changes 
that may well persist even beyond the teenage stage into adulthood. Nicolaides (2015) states that in an Ubuntu society such as South Africa, it is incumbent on young women to be cared for so that there can be some gender equity, especially given that many young women are sexually abused. They need to feel liberated to report such issues.

Teenagers themselves agreed that the family provided the primary social learning for their behaviour during their teenage stage. Their parents did however, for the most part often try to teach them consumer skills, and some also taught them to exhibit good social behavior. However, parents instill discipline their children also tend to exhibit poor interpersonal communication that affects them and leads to various unacceptable behaviours

\section{Observation of teenagers' aggressions}

This section sought to analyze the predictive capacity of some individual, family, and community variables concerning the likelihood that a teenager will engage in aggressive behavior toward others. Some teenagers are aggressive because of bad examples seen when using a mobile phone or the Internet, which may occasionally or intensely control for the effect of potential confounding variables.

The findings revealed that the aggressive behavior of some teenagers is sometimes caused by the way that they were nurtured as a child. Not only the way that a child is nurtured, but also the experiences in life faced as a child grows up. Some were abused by people from community and others by members of their families but the cases of child abuse were not reported due to the fear and secretiveness of the child involved. The majority of teenagers were abused by their family member and the cases are often not reported. Others were abused physically, emotionally and sexually. They also agreed that the MCSA in PE North does indeed offer some pastoral care through the ministers of the circuit.

The church has different programmes concerning with the welfare of the individual child. MCSA in the PE North Circuit not only cares for the spiritual side of a child but also the physical and emotional side of children and it creates a space for children to express themselves. Children may exhibit inappropriate sexual behavior and/or sexual abuse toward other children and need counselling on such actions. Sexually abused children may also exhibit changes in behavior. Stark (2015) argued that the psychological effects of child sexual abuse last well into adulthood. Survivors may feel stigmatized and experience low self-esteem, depression, grief, guilt, shame, self-blame, rage, anxiety, fear, and panic attacks. Teenagers that were sexually abused may become very depressed, immoral, aggressive, or even angry and may experience powerlessness, eating issues, nightmares or sleep disturbances, or perhaps even fear that an incident will recur.

The teenagers that were sexually abused are often distrustful, have difficulty developing and maintaining relationships, and often feel that they have poor or no support systems. They thus tend to be re-victimized, self-mutilate, or even attempt suicide. Stark (2015) argued that not everyone who is sexually abused experiences negative effects. Furthermore, he however further states that those who are negatively affected by sexual abuse suffer with feelings of distrust, guilt, depression, identity confusion, low self-esteem, and emotional and have intense relationship issues. Those teenagers may exhibit self-abuse and antisocial behavior whereas some behaviours are consequences of sexual abuse at the same time that they are risk factors for revictimization. 


\section{Findings and Contribution to the body knowledge}

The research study approach to the topic accepts that teenage care must be a starting point to reflect the role of the Methodist Church of Southern Africa (MCSA) especially relating to teenage care in the Port Elizabeth North Circuit of the Eastern Cape Province in South Africa. The twenty two respondents were interviewed; their responses were analyzed and presented by the researcher. The effects of religiosity and church support on the well-being of youths and also adolescents will invariably lead to a sound religious upbringing and positive social and emotional functioning on the receivers end.

Furthermore the researcher recommends that there is need for the MCSA to have committees that will formulate structures for sustaining projects and give an account of finance utilization as many teenagers drop out from school due to severe financial constraints. The MCSA, Department of Social Development, NGOs and the Department of Health should work together to strategize on structuring the welfare of children in communities general. Furthermore, the MCSA should also take into account all the special conditions that are associated with child abuse. The Methodist Church should develop a teenage care policy and integrate it into its existing polices. Through spiritual development, the children can learn to be conscious of and contented with qualities such as respect, responsibility, and respect for self and also others. They need to be guided by ministers to learn to be capable of acknowledging differences between people without feeling fear to state when something bad befalls them so that they can develop into useful citizens in society. A child who has to learn to believe other people and may find it difficult to trust God and God's care for him or her. The child's needs to be nurtured so as to have an ability to trust and respond to those who have the chief responsibility for their care. This aspect is a critically important foundational aspect for their future development. Obtaining support from a local church will enhance the youth's psychological adjustment and social competence for spiritual and decent living.

\section{References}

Antwi, S.K. \& Hamza, K. (2015). Qualitative and quantitative research paradigms in business research: A philosophical reflection. European journal of business and management, 7(3), 217225.

Babbie, E. (2010). The practice of social research. Wadsworth: USA: Learning Customer \& Sales Support.

Baumgartner, J.J. \& Buchanan, T.K. (2010). Supporting each child's spirit, Young Children, 65(2), 90-95.

Bridges, L.J. \& Moore, K.A. (2002). Religion and Spirituality in Childhood and Adolescence, Child Trends, January, 2002

Chisale, S.S. (2014). Pastoral Care with children in a context Of HIV and Aids: Towards a contextual pastoral care model with Unaccompanied Refugee Minors (URMS) from Zimbabwe in the Methodist Church Community Centre in Johannesburg. Unpublished Thesis. University of South Africa: Pretoria.

Cheng, T.L. and Conca-Cheng, A.M. (2020). The pandemics of racism and COVID-19: danger and opportunity, Pediatrics, 146(5). 
Coulson, S. (2010). Getting 'Capital' in the music world: musicians' learning experiences and working lives. British Journal of Music Education, 27(3), 255-270.

Denzin, N.K. and Lincoln, Y.S. (eds). (2011). The Sage handbook of qualitative research. Sage: NY.

Doka, K.J. (2011). 'Adolescence, identity and spirituality'. The Huffington Post. [Available online at http:// www.huffingtonpost.com (Accessed 19/09/2017).

Donald, D., Lazarus, S. \& Peliwe, L. (2007). Educational Psychology in Social Context (3rd ed). Cape Town: Oxford University Press.

Gee, C., Maskell, J., Newcombe, P., Kimble, R. \& Williamson, H., (2020). Australian health professionals' perspectives of psychosocial adjustment to visible differences: a qualitative analysis of pediatric populations. Body image, 33, 13-26.

Hadley, L.C. (2007). Spiritual Support: A Pastoral care Model for Children and Teens in Trauma. Unpublished Doctoral Thesis, United Theological Seminary Trotwood, Ohio.

Heimbrock, H.G. (2010). Beyond secularization: Experiences of the sacred in childhood and adolescence as a challenge for RE development theory, British Journal of Education, 26(2), 119131.

Hobkirk, A., Watt, M. Myers, B. Skinner, D. \& Meade, C. (2016). "A qualitative study of methamphetamine initiation in Cape Town, South Africa". International Journal of Drug Policy, 30, 99-106

Kopchak Sheehan, D., Burke Draucker, C., Christ, G.H., Murray Mayo, M., Heim, K. \& Parish, S., (2014). Telling adolescents a parent is dying. Journal of palliative medicine, 17(5), 512-520.

Kim, K. \& Anderson, A. (eds.). (2011). Mission today and tomorrow. Regnum: Oxford.

Lefrancois, G. R. (2011). Of children: An introduction to child and adolescent Development. Wadsworth Group: USA.

Lebese, R.T., Ramakuela, N.J. \& Maputle, M.S. (2014). Perceptions of teenagers about substance abuse in Muyexe village, Mopani district of Limpopo Province, South Africa African: Journal for Physical, Health Education, Recreation and Dance, December (Supplement 1:2), 329347.

Malinga, P. \& Richardson, N. (2006). Rediscovery Wesley for Africa: Themes for John Wesley for Southern Africa today. Education for Ministry and Mission Unit: Pretoria.

MacAdams, D. P. (2013). The redemptive self. Oxford University Press: New York.

Mihajlović, J. Tasovac, P., Dikanović, V., Vignjević, Z. (2000). Slobodno vreme i fi zička aktivnost u 14. Beogradskoj gimnaziji, Zdravstveno ponašanje studentske I srednjoškolske omladine (Zbornik), Zavod za zdravstvenu zaštitu studenata Beograd, 11-14. 5. 2000., Zlatibor, 186-187.

Mokwena, K. E. \& Huma, M. (2014). Experiences of 'nyaope' users in three provinces of South Africa. African Journal for Physical, Health Education, Recreation and Dance, September (Supplement 1:2), 352- 363. 
Ndlangisa, A. (2012). Teenagers and Alcohol: A guide for parents. Article from the December 2012 issue of Bona Magazine, South Africa.

Nicolaides, A. (2020).Contemplating Christian ethics and spirituality for sound leadership in organisations, Pharos Journal of Theology, 101: a37.

Nicolaides, A. (2015). Gender equity, ethics and feminism: Assumptions of an African Ubuntu Oriented Society, Journal of Social Science, 42(3), 191-210.

Osmer, R.R. (2011). Practical theology: A current international perspective, HTS: Theological Studies, 67(2), 1-7.

O'Neill, V. (2011). Psychology: An Introduction. Oxford University Press South Africa (Pty): Cape Town.

Piaget, J. (1972). Intellectual evolution from adolescence to adulthood, Human Development, 15 (1), 112. https://doi.org Viewed 27 October 2018.

Primavera, J. \& Jackson, S.A. (2013). Salem Press Encyclopedia of Health: Child Abuse, Journal of Psychology: Sabinet SA Publications.

Qambata, N.A. (2011). A descriptive study on experiences of teenage mother attending Notyatyambo Health Care Centre, Eastern Cape with regard to child care. Masters, University of Fort Hare.

Smit, G.H. (2015). Pastoral ministry in a missional age: Towards a practical theological understanding of missional pastoral care, Verbum et Ecclesia, 36(1), 1-8.

Srivastava, N., Nyamathi, A.M., Sinha, S., Carpenter, C., Satyanarayana, V., Ramakrishnan, P. \& Ekstrand, M, (2017). Women living with AIDS in rural Southern India: Perspectives on mental health and lay health care worker support, Journal of HIV/AIDS \& social services, 16(2), 170-194.

Wang, C., Hipp, J.R., Butts, C.T., \& Lakon, C.M. (2018). The interdependence of cigarette, alcohol, and marijuana use in the context of school-based social networks, 13(7). [Available online at https://doi.org /10.1371/journal.pone.0200904]

White, K.J. (2011). 'Children as signs of the kingdom of God - A challenge to us all', in Arles, S. Brewster, D., Kok, C.B., Tan, R. \& White, K.J. (eds.) Now and next. A compendium of papers presented at the Now and Next Theological Conference on Children, pp. 41-61, C.O.S Printers, Singapore.

Yilmaz, K. (2013). Comparison of quantitative and qualitative research traditions: Epistemological, theoretical, and methodological differences. European Journal of Education, 48(2), 311-325.

Yohani, S. (2010). Nurturing hope in refugee children during early years of post-war adjustment, Children and Youth Services Review, 32(6), 865-873. 